Hamline University

DigitalCommons@Hamline

$10-2013$

\title{
Landscape ideology in the Greater Golden Horseshoe Greenbelt Plan: Negotiating material landscapes and abstract ideals in the city's countryside
}

\author{
K. Valentine Cadieux \\ Hamline University, kvcadieux@hamline.edu \\ Laura E. Taylor \\ York University, Canada \\ Michael F. Bunce \\ University of Toronto, Scarborough
}

Follow this and additional works at: https://digitalcommons.hamline.edu/cla_faculty

Part of the Growth and Development Commons, Human Geography Commons, and the Place and Environment Commons

\section{Recommended Citation}

Cadieux, K. Valentine; Taylor, Laura E.; and Bunce, Michael F., "Landscape ideology in the Greater Golden Horseshoe Greenbelt Plan: Negotiating material landscapes and abstract ideals in the city's countryside" (2013). College of Liberal Arts All Faculty Scholarship. 1.

https://digitalcommons.hamline.edu/cla_faculty/1

This is the author's submitted copy before peer reviewed edits. The final, definitive version of this document can be found online at Journal of Rural Studies published by Elsevier. Copyright restrictions apply. doi:10.1016/ j.jrurstud.2013.07.005

This Article is brought to you for free and open access by the College of Liberal Arts at DigitalCommons@Hamline. It has been accepted for inclusion in College of Liberal Arts All Faculty Scholarship by an authorized administrator of DigitalCommons@Hamline. For more information, please contact digitalcommons@hamline.edu. 


\title{
Landscape ideology in the Greater Golden Horseshoe Greenbelt Plan: Negotiating material landscapes and abstract ideals in the city's countryside
}

Keywords: Toronto; critical landscape studies; cultural geography; collaborative environmental management; growth management; political ecology; urban rural interface; peri-urban fringe; exurbia; anti-sprawl policy

\begin{abstract}
:
We analyze the role of landscape ideology in the recent Ontario Greater Golden Horseshoe (GGH) Greenbelt Plan. Focusing on the "Protected Countryside," the major land-use designation in the Plan that structures the Greenbelt framework, we explore tensions between abstract ideals of countryside used by policy makers to elicit support for the Plan and people's lived experience of material landscapes of the peri-urban fringe. Approaching "countryside" from the combined perspectives of landscape studies and political ecology, we show how the abstract ideals used to build support for the protection of countryside in the high-level political arena are in tension with existing material landscapes as people experience them. When implementing the Greenbelt Plan, the abstract ideals have to be applied at the landscape level through negotiation with municipalities, property owners, and other interests. In addition to drawing upon more conventionally legitimate explanations for landscape protection based on environmental science and land-use planning principles, the designation of Protected Countryside and the strategies used to implement the Protected Countryside designation at the local level suggest a tentative commitment to recognizing landscape values and collaborative environmental management processes in policy-making. As with any such normative land-use plan, the success of the Greenbelt Plan hinges on the long-term agreement between planning agencies and diverse publics. We demonstrate the usefulness of approaching environmental management challenges at the urban-rural interface by bringing the perspectives of landscape studies and political ecology into implementation processes for land-use management strategies like the Greenbelt. We argue that public participants deserve legitimate collaborative roles in negotiating just and desirable land uses based on their experiences, and provide observations on ways to bring contested goals and tools for achieving them into reflexive negotiations about how landscapes are and should be produced.
\end{abstract}

\section{Protected Countryside: Using an iconic landscape as a policy tool}

This was not purely a growth management tool; this was meant to be an enduring legacy. We had goals we identified in terms of what the Greenbelt would accomplish going forward. First and foremost, we saw this as being a very important amenity - maybe amenity is too soft a word, but—feature for the urban dwellers. So this Greenbelt, in our view, is every bit as important to people living within the cities as it is to people living within the Greenbelt. Our whole community, our whole society, has a really important interest, a distinct interest, in making this happen. We said that the Greenbelt should provide greenspace and mixed open space; that it should act as an urban separator, that it should help define communities, provide a sense of place for communities. It should protect ecological features and functions. It should preserve agricultural land, viable agricultural land-because if we're going to save something as agriculture, it was our view that 
it needed to be farmable. We thought the Greenbelt should sustain our countryside and rural communities, that it should conserve natural resources, and we also talked about infrastructure, and how infrastructure should relate to the Greenbelt. Our document is somewhat like a fabric, we had those goals, and then interlaced through those goals, we identified layers of different aspects of the Greenbelt, so our document is really organized around these layers: environmental protection; agricultural protection; natural resources; infrastructure; culture, tourism, and recreation. (MacIsaac, 2004)

In December 2004, the Ontario government passed legislation to create a 730,000 hectare Greater Golden Horseshoe (GGH) Greenbelt around the Toronto area to tackle urban sprawl (OMAH, 2005). ${ }^{1}$ The management of urban growth has been a perennial policy issue in the Toronto region, one of the largest and most rapidly growing areas in North America. Public outcry over the loss of rural landscape to urbanization has repeatedly brought sprawl to the top of the Ontario provincial government agenda. Devised as a provincial-level response to public concerns about urbanization of Toronto's fringe, the Greenbelt is a collection of lands already protected through other legislation plus a new Protected Countryside (see Figure 1: GGH Greenbelt Plan Area), a land-use designation comprising over half of the Greenbelt. ${ }^{2}$ As such a large proportion of the Greenbelt's area and as the only lands solely governed by new legislation, the landscapes of the Protected Countryside occupy a pivotal position in the Plan, particularly in the way that the Plan's implementation is understood, experienced, and negotiated at the local level. With the creation of the Greenbelt, the fringe landscape of Canada's largest city has been

\footnotetext{
${ }^{1}$ The "Greater Golden Horseshoe" is used now to describe the regional planning area around Toronto that hugs the western shores of Lake Ontario. The area includes: the "Greater Toronto Area" (the GTA includes the Regions of York, Durham, Halton, and Peel plus the City of Toronto); the City of Hamilton; and the Region of Niagara, with a geographical extent of over $31,000 \mathrm{~km}^{2}$ and 2011 population of 9 million people, anticipated to grow to 13.5 million by 2041 (Hemson, 2012). We refer to the GGH Greenbelt as "the Greenbelt" and the legislation governing it as "the Plan."

${ }^{2}$ Existing areas protected by legislation and now brought under the umbrella of the Greenbelt Plan include: the Niagara Escarpment Plan (starting in the early 1970s, NEC 2005), the Oak Ridges Moraine Conservation Plan (OMAH, 2002), the largely defunct Parkway Belt West Plan (Ontario MTEIA, 1978), and the recent Rouge Park Management Plan (Ontario, 2004). The Greenbelt as "umbrella" signals a return to the centralized rationalization of land-use planning, which is concurrent with a devolution of implementation to local levels (not just an Ontario phenomenon). Our analysis seeks to provide tools for better negotiating the dialectical nature of this processbetween scales of governance and between differing types of expertise.
} 
rebranded "countryside." Countryside, in this case, signifies the landscape where nature is enjoyed, where local food is grown and natural resources are stewarded — features all now protected by legislation from urban sprawl. ${ }^{3}$ As a combined urban and regional growth management boundary and tool for landscape protection and functional designation, the Protected Countryside is significant to those interested in the recurring failure of attempts to govern urban-rural landscape relationships.

This failure is "sprawl." This struggle over sprawl has been highlighted in recent calls for greenbelt reform. For example, in Australia and the UK, greenbelts prohibiting all development are seen as relics of the post-World War II period, needing to be reviewed in light of contemporary concerns with sustainability of both the environment and the economy of the urban areas they constrain. In Japan and Korea, greenbelts created for military purposes are seen as incongruous with present-day pressures on available land (see Amati and Taylor, 2010). As scholars and practitioners, we witness tensions involved in governing the intersection of urban and rural landscapes, which are significantly influenced by the ideology of countryside and nature. Although "countryside," "nature," and "rurality" are often treated as taken-for-granted aesthetics or logics guiding land-use management, we argue that ideological landscape abstractions do important (and often problematic) work and need to be better and more explicitly acknowledged and given space for negotiation in environmental policy frameworks. For example, three key themes we discuss here and elsewhere include: (1) negotiation of urban and rural ideals of environmental management; (2) the persistent effects of anti-urban ideologies and

\footnotetext{
${ }^{3}$ The Greenbelt Plan was passed by the Ontario Legislature in February 2005 about a year after the declaration of a greenbelt study area encompassing the entire GGH region, which involved a moratorium on development approvals outside of urban boundaries. During the study period, a task force developed the policy framework for the Plan and conducted a series of public meetings and workshops across the region as well as a web campaign to seek input. The Greenbelt Plan is paired with an urban growth management strategy ("Places to Grow," OPIR, 2006), which guides growth within urban areas contained by and adjacent to the Greenbelt.
} 
aesthetics on rural landscape planning; and (3) difficulties mediating competition between urban and rural social economies and systems of land use (Bunce, 1994; 1998; Bunce and Maurer, 2005; Cadieux, 2011; Cadieux and Taylor, 2012; Taylor, 2007; 2010; 2011).

Dealing with these challenges has raised interest in how landscape conflicts are expressed and addressed through plan implementation—not just in the visioning and policy-making processes - especially at the urban-rural fringe (von der Dunk et al., 2011). However, although scholars and practitioners denounce sprawl and promote alternative urbanization practices and conservation measures to address the social and other systemic costs of sprawl, both are often complicit in this failure via their implementation of expert plans that are not open for negotiation. Using the Greenbelt as a case study of land-use policy effort in which collaborative environmental management has been an explicit aspiration, even if not quite realized, we demonstrate in this article how insights from the combined conceptual frameworks of landscape studies and political ecology can be used to better understand conflicts at the urban-rural interface. We suggest from this analysis ways these might be addressed in environmental planning, improving outcomes by enriching collaboration between participants in these processes and also between geography and environmental planning fields.

In this article we critically explore the Protected Countryside designation in relation to the existing landscapes that it sets out to protect, and then propose some points to consider regarding the implementation of land-use policies for the Protected Countryside within the Greenbelt Plan. Our discussion is timely as the Greenbelt is undergoing its 10 -year review in 2015 when the performance of the Plan, its policies, and their implementation will be evaluated. Having observed conflicts and tensions as participants in and observers of the process leading up to the adoption of the current Greenbelt Plan, and believing that the Greenbelt process could 
enable a valuable participatory engagement with landscape, we explore the tensions between the ideal abstract countryside and the material countryside in the Greenbelt Plan by first looking at the discursive representation of countryside as a way to conceptually divide urban and rural landscapes, and then considering the ways that agriculture and ecology are used to promote different kinds of systemic thinking about the Protected Countryside landscape.

Our argument that a landscape framework could help to support negotiations over landuse-planning decision making has developed in relation to our own situation within the political and epistemological context of the Greenbelt Plan. We have worked as planning educators and practitioners, political advisors, and publicly-engaged researchers in the Toronto region. Participation in the political process that led to the Greenbelt gives us a well-situated perspective on the ideas that contributed to the Greenbelt Plan in general, and the references to countryside in particular. The nature of this participation includes appointment to the original Greenbelt Task Force on the proposed Greenbelt Plan of one of this article's authors, Michael Bunce, in 2004. All authors have been participants (in some cases as panellists and in others as audience members) in the public consultations on the Greenbelt Plan (in 2004). All have also participated in policy and academic conference discussions, as well as course discussions, intensive field studies, and focus groups convened by the authors about land use management in the landscape that became the Greenbelt, and the subsequent implementation of the Greenbelt Plan—extending from the early 2000s to the present, a moment during which affected constituencies are considering how to participate in the first mandated ten-year review of the Plan (Sections 5.6$5.9^{4}$ ). These sessions have included members of the public, provincial and local bureaucrats and politicians who have participated in the formation and implementation of the Plan, as well as

\footnotetext{
${ }^{4}$ All references to "Sections" are to sections of the Greenbelt Plan (OMAH, 2005).
} 
scientists, academics, and international visitors interested in the Plan. In late 2010, Laura Taylor was appointed to the Greenbelt Council, which gives advice to the Minister of Municipal Affairs and Housing on matters of the Greenbelt. Moreover, our participation in public discourse on the relationship between urban and rural land-use planning in the region, particularly over the past two decades, talking to different people about how they understand the countryside and what they desire in terms of future incorporation of rural land within the Toronto region (and in comparable regions), gives us a broad and detailed view of how the multiple meanings of countryside are being negotiated between different actors in the Greenbelt process (and in parallel cases) - in terms of the way the countryside is used, inhabited, and represented, and also in the ways that conflicts between uses and representations are staked, argued, and resolved. ${ }^{5}$

\footnotetext{
${ }^{5}$ In addition to following comparative discussions around the GGH Greenbelt (for example at the March 2011 Global Greenbelts Conference hosted by the Friends of the Greenbelt Foundation), the authors have been involved in research programs related to other debates over the implementation or revision of Greenbelt designations, for example in Christchurch (Cadieux, 2008) and Minnesota; see also Amati and Taylor, 2010. Please contact the authors for more information on their archive of extensive field notes taken on the meetings and negotiations in which they have taken part.
} 


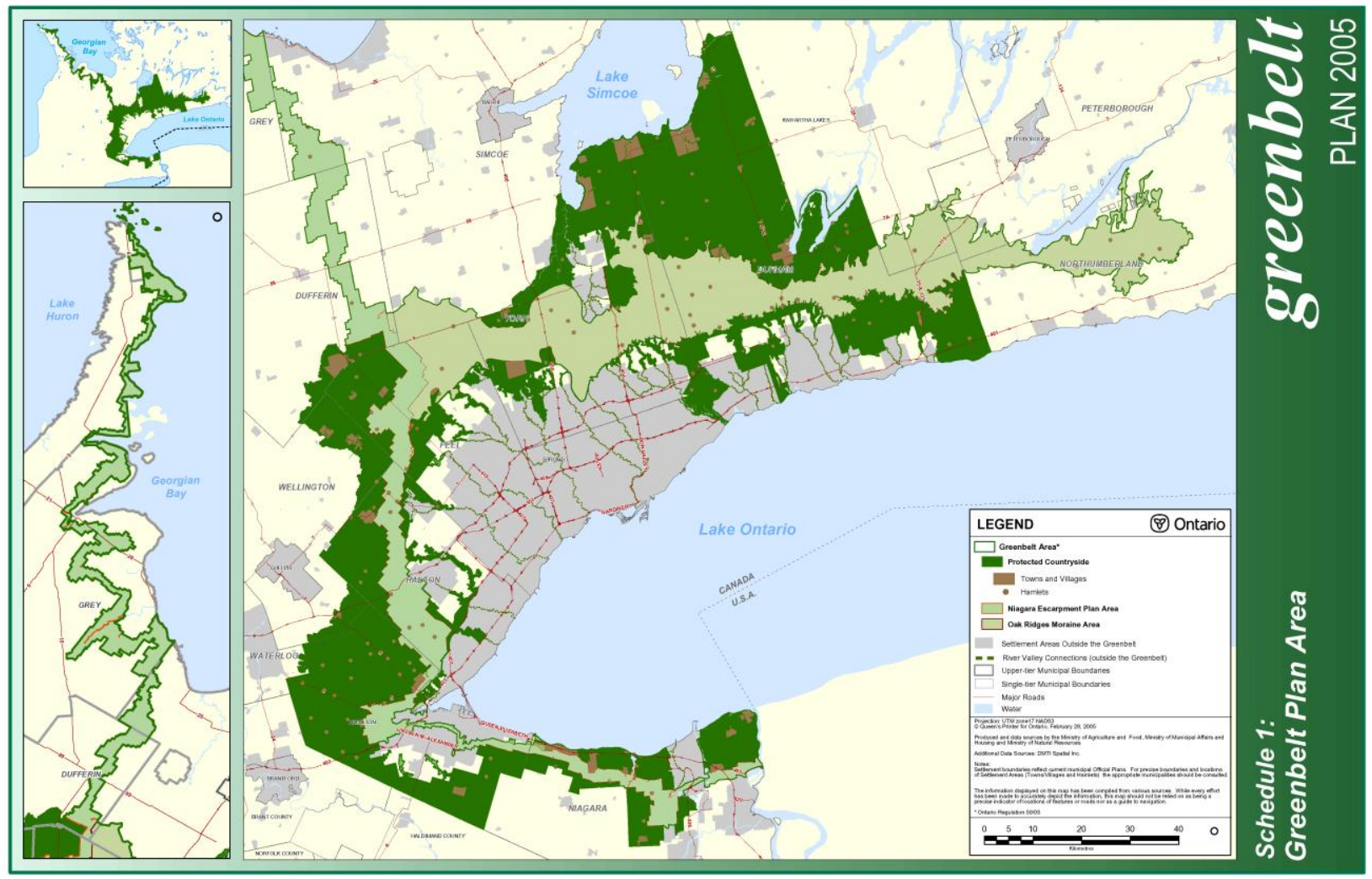

Figure 1: Greater Golden Horseshoe Greenbelt Plan Area, showing Protected Countryside, from the Greenbelt Plan (OMAH, 2005)

A central tenet of our argument is that environmental governance works best if diverse constituents' environmental goals are sincerely engaged (Innes and Booher, 2010). In analyzing the case study of the GGH Greenbelt, our goal is to show how tensions between and within the policy goals might be better addressed in the emerging style of environmental governance process of which the Greenbelt Plan process is nominally an excellent example. For example, governing bodies might commit to equitable, long-term frameworks for negotiation, and define success in terms of collaboratively identified performance measures of both the processes and the outcomes (Smith et al., 2011; Plan Section 5.9). 
Included as part of a suite of provincial-level policy developments designed to guide municipal-level planning across sectors and across the region, the Plan has been an important centerpiece of the Ontario Liberal Party's commitment to address quality-of-life needs in the face of rapid urbanization (Plan Section 1.1), particularly in contrast to a previous provincial government that was widely perceived as overly lax in the oversight of urbanization processes, leaving urban edge landscapes vulnerable to municipal regimes highly influenced by development interests (Tomalty and Komorowski, 2011). Partly because of this recent history, the Greenbelt process has been characterized by a rhetoric of inclusivity, for example, with the 2011 Global Greenbelts Conference organized by the Friends of the Greenbelt Foundation characteristically emphasizing the "essential role of citizen involvement," the diversity of greenbelts, and the "mix of policymakers, practitioners, academics and advocates" that need "to share ideas and forge an ongoing collaboration" in order "to build political will to sustain greenbelts" (Friends of the Greenbelt Foundation, 2011: 3). We have not seen such inclusivity in practice.

When the Greenbelt was announced, Ontario’s Premier was widely quoted saying, “Our goal is to build a legacy for our children, one that includes protecting thousands of acres of prime farmland so farmers can prosper, preserving our watershed, rivers and forests to protect the water we drink and the air we breathe [and] promoting recreation, sports and tourism by establishing a trail system, open spaces and parkland" (McGuinty, 2004). The Greenbelt's intent was explained as bringing "real, positive change to the quality of life in the Golden Horseshoe" (OMAH, 2003). From the landscape studies, political ecology, and collaborative environmental management perspectives we bring to the case, the success of the Greenbelt living up to these goals rests in 
large part on how the implementation process is carries out, creating landscape change or continuity.

The Greenbelt Plan frames the process by which individual municipalities implement and manage Greenbelt landscapes in language that reflects collaborative environmental management values and processes - particularly the idea that collaboration amongst diverse stakeholders in decision making is desirable (Conley and Moote, 2003; Opdam, Steingröver, and van Rooij, 2006; Section 5.9). For instance, Section 5.9 of the Greenbelt Plan discusses the implementation of the plan and identifies the need to "coordinate efforts" between "municipalities, conservation authorities, associations and other stakeholders." The need for a politically—as well as environmentally—successful outcome created an incentive and opportunity for deliberately following a collaborative environmental management approach. As While and colleagues discuss (2010), the importance of understanding the function of such an approach becomes more evident in the face of the devolution of environmental regulation in urban and regional governance. The success of such regulation rests on collaboration across scales of governance and diverse perspectives.

As municipalities have amended their planning policies and practices to reflect the Greenbelt legislation, opportunities and obstacles have arisen for living up to the promises of the Greenbelt. ${ }^{6}$ As a provincial plan, the Greenbelt Plan is broad in scope, providing overall policy guidance for the Protected Countryside but leaving the specific details up to local authorities. It

\footnotetext{
${ }^{6}$ The Greenbelt Plan is a provincial plan requiring all local municipalities to conform. In Canada, the provinces are charged with land-use planning and in the Toronto area there are two tiers of municipalities - regional and localwhich are required to update their local comprehensive plans to reflect and implement provincial policy. In contrast perhaps to other jurisdictions with greenbelts, the new Ontario Greenbelt included lands already subject to institutionalized regional planning where the line between urban (serviced) and rural (very limited subdivision) was tightly controlled, with urban boundary expansions only permitted through major planning studies. The cry to "stop sprawl" was in fact a cry to stop planned urbanization. The fringe landscape around Toronto is nevertheless a messy rural landscape with industrialized farms, exurban homes on historically severed lots, re-naturalizing farmland under speculation, and urban uses exempt from land-use policy.
} 
is up to local municipalities to "delineate" and "refine" boundaries of features of the "natural heritage system," "prime agricultural areas," and "settlements" internal to the plan (Section 5.5.2) in their comprehensive plans, as well as to include policies in those plans to ensure local planning and development practice conform to the Greenbelt Plan. This Canadian governance structure solves many of the regional coordination issues faced by jurisdictions in other places, especially the United States, where landscape-scale protection is achievable through voluntary local cooperation (Ryan et al., 2006). Because the new parts of the Greenbelt have been organized around the central concept of Protected Countryside, the success or failure of the whole greenbelt concept hinges on the widespread recognition that a zone of Protected Countryside in the Toronto region makes sense - and many of the conflicts relating to the Greenbelt involve the Protected Countryside designation. Tensions are evident between competing visions of countryside — as farmland or as desirable place to live, for example — and also within specific ideals of countryside, as images of countryside are cobbled together out of an aesthetic of nature and scenic agriculture. This contributes to clashes between romantic ideals of countryside with contemporary farming practices.

Along with the "natural system" (Section 3.2), for example, agriculture has been cast as the defining land use for the Greenbelt's Protected Countryside (Section 3.1). Because protecting agricultural land uses is represented as central for the Countryside, the Greenbelt Plan relegates other uses to minor roles, and masks internal tensions and complexities around nature, agriculture, and urbanization. Natural systems, recreational areas, and cultural heritage protection have been, in many ways, traditionally regulated around an agricultural hegemony — an historical ideal that values a dominant form of agriculture as the default use for any arable rural land. This ideal, however, is only vaguely understood by many Greenbelt supporters, leading to conflicts 
between abstract endorsement of agricultural aesthetics but substantive objection to material practices of farming. Farmers have been allowed to carry on with significant landscape-shaping activities, but the conflation of rowcrop agriculture with countryside has exacerbated clashes between the visions for a farming aesthetic in harmony with natural systems promoted by many urban environmentalist supporters of Greenbelt farming (but decidedly not of corn and soybean agriculture) and the agricultural practices and cultures of existing cash grain producers in the rural Greenbelt. In opposition to farmers' demands, the Protected Countryside has largely removed the speculative land economics that have supported farm operations and has imposed a new version of the environmental stewardship role in the service of the urbanites' view of the countryside landscape.

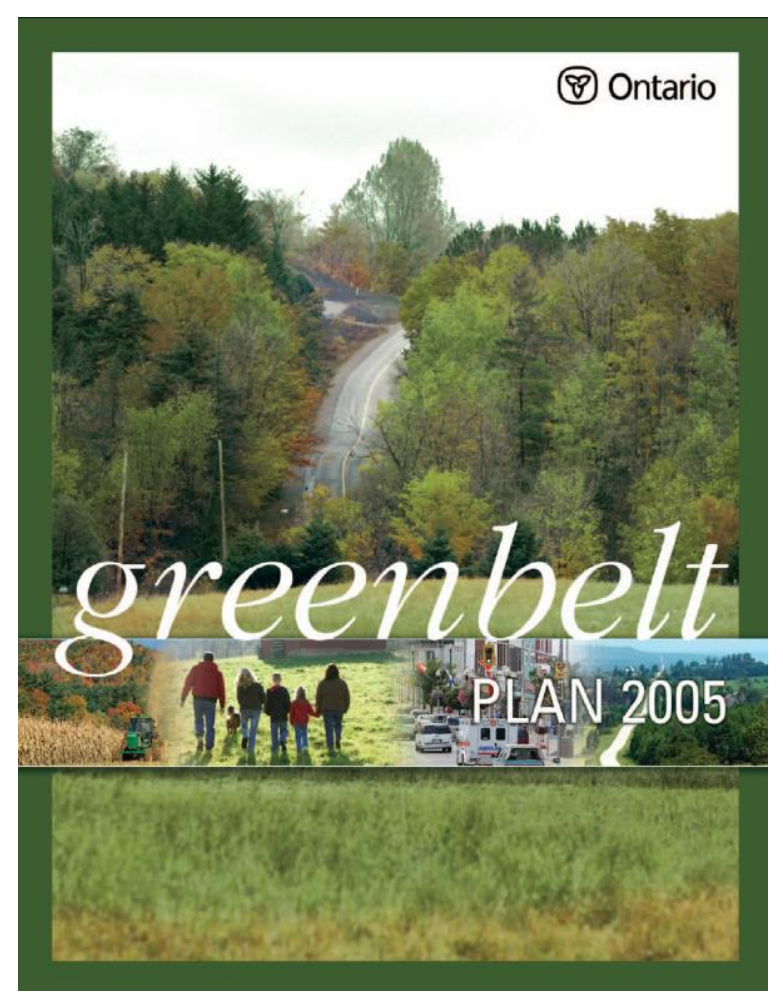

Figure 2: The lack of emphasis on productive agriculture in the Greenbelt Plan's cover photograph suggests tensions between ecological and agricultural values in the Protected Countryside (OMAH, 2005) 
The Greenbelt Plan's cover photograph clearly illustrates the tension between ecological and agricultural values in the Protected Countryside. Although the ecological outputs of the natural system are clearly understood to be at least in theory compatible with agricultural land use (Section 3.1.1), the full-page color photograph of Greenbelt landscapes devotes only about one percent (less than 3 square centimeters) to agriculture (a tractor in a hilly field of corn—and even there, two thirds of the photograph is hillside forest). And although the biodiversity of a landscape with both farms and forests may contribute to an attractive environment with health and ecosystem benefits for farming as well as exurban residents, from a farming perspective, the recent regrowth and reverting pastureland pictured does not look like conventionally successful agriculture. The mixed representation of ecologically benign reforestation and scenic fields for hiking and driving through, however, do perhaps accurately display the priorities for recreational and residential uses that frame the countryside from an urban perspective, and starkly illustrate some of the challenges for negotiating agricultural land-use standards between constituencies who imagine agriculture in very different ways.

Although various forms of farming provide a reasonable livelihood for some and, cumulatively, make a significant contribution to the region's food supply and general economy (Walton, 2003), undercurrents of insecurity affect different parts of the agricultural countryside in different ways (Bunce and Maurer, 2005). In the strips of Protected Countryside squeezed between the suburban edge of greater Toronto and the Oak Ridges Moraine and Niagara Escarpment, in south Simcoe County and much of the Niagara region, agriculture confronts contradictions of operating in a peri-urban setting - for instance, the benefit of local markets for direct sales and a supply of cheap rental land from developers, on one hand, accompanied by uncertainty in land tenure and the difficulties of carrying out farm operations in suburbanizing 
locations, with increased traffic and non-farm neighbour complaints, on the other (Bunce and Maurer, 2005).

Our observations of considerable slippage and misunderstanding of the meanings of countryside involved in this negotiation motivated us to prepare this paper to explicitly lay out an exploration of countryside within landscape studies and political ecology in order to contribute to local implementation and evaluation frameworks, and also to use this as a case study testing the growth management, rural land protection, and collaborative environmental management theories that motivated our interest in this Greenbelt case in the first place.

\section{Situating Greenbelt policy creation in a critical landscape studies framework}

We situate our analysis of the Protected Countryside within landscape studies and political ecology (Walker and Fortmann, 2003; Hurley and Walker, 2004; Robbins 2011). We analyze the discourses used to organize and support the Greenbelt Plan in order to consider the political implications of understanding countryside as a contested landscape and also to see how the meanings associated with "countryside" play out in the implementation of the Plan. Critical interpretation enables us to analyze how tensions and slippage between the abstract ideal and the material lived landscape may inhibit a nuanced understanding of the complex cultural landscape at the city's edge by and between those involved in shaping its future and, over the long term, challenge the successful implementation of the Plan.

Our motive for considering the case of the Greenbelt in the context of landscape studies is twofold. First, the idea of landscape is relevant to the multi-stakeholder implementation process that has been envisioned in the Plan for translating the Provincial Greenbelt Plan into local action and land-use planning. Public environmental management, such as greenbelt 
implementation, should address the interplay between material and ideal landscapes more than it does. Although the landscape approach is familiar to those in geography, landscape architecture, and related fields of study, the concept of landscape as the product and process of societyenvironment interaction has not been introduced, much less adopted, as a cogent framework for integrating multiple and often competing environmental values in many other applied areas such as environmental management and planning. Our landscape analysis suggests that the processes for implementing and evaluating the Greenbelt will be improved (i.e. more accessible, diverse, satisfying, and likely to address goals manifested in the Plan and in the political action leading to it) if the tension between material landscape and landscape abstraction — and the assumptions and ideologies upon which such abstraction is based - are open for engagement (cf. Antrop, 2005; Demeritt, 1994; Hajer, 1995; Woods, 2010; Wylie 2010). Collaborative environmental management approaches provide excellent frameworks for applying and testing such open engagement. To our knowledge, public acknowledgement and negotiation of the impact of the symbolic on the material in the planning process has not been revealed in a case study such as ours.

Second, beyond our interest in this specific intervention, the Greenbelt process exemplifies a fundamental challenge in growth management strategies common to a wide range of places. Based on our experience, in many growth management strategies, the use of abstract, imagined, idealized landscapes as discursive representations in policymaking creates disjunctures with the on-the-ground material landscapes that become subject to planning designations and that often do not conform to abstract ideals. As von der Dunk and colleagues (2011) observe in their study of peri-urban conflicts in Switzerland, such tension between the abstract and the ideal lead to disconnects between the ways that land-use conflicts are stated in planning processes and 
policy documents (for example where there are agricultural and natural landscapes that clearly should not be urbanized, Section 1.1) and the much more ambiguous and conflicted ways that people experience urbanization as they struggle to articulate their stances in relation to sitespecific concrete proposals and their attachments to tangible landscapes (however much the experience of these material landscapes may be influenced and mediated by various layers of abstraction). The problems involved with such disjunctures between abstract and material landscapes highlight the need for negotiation in the implementation process between people with different landscape goals - especially those with different understandings of existing landscape processes.

Better understanding of the ways that different actors use abstraction in policy-making and implementation may be particularly useful for those struggling to reconcile existing and desired landscape outcomes, especially when the use of abstraction is a deliberate and explicit political strategy, as in the case of the Greenbelt (Stein and Anderson, 2002). "Abstraction participates in processes of world-making" because it helps actors understand and discuss the complexities of the lived world (McCormack, 2012). Incorporation of diverse goals helps create management regimes that are more resilient and representative (Cadieux, 2011; Innes and Booher, 2010).

Looking at Greenbelt policy making from the perspective of landscape studies and considering the countryside of the Greenbelt Plan area as a contested landscape opens up analytic possibilities for seeing the tensions at work in the category of Protected Countryside. In cultural geography, landscapes are seen as produced by natural and cultural processes as they are lived in by both humans and non-humans over time. Landscapes are at once artifacts of culture that we see and experience and, as such, are understood as politically charged and susceptible to political 
readings (Duncan, 1990: 7) and also as lived interpretations of what takes place there (Anderson and Harrison, 2010). Landscapes (city, suburb, wilderness, country) can be examined in the context of "discursive practices" within which they make sense to people in specific times and places (Duncan, 1990: xiv). These discursive and behavioral practices are part of what people use to create and maintain meaning in shaping and re-shaping landscapes; this interpretation provides a perspective with particularly important traction in considering the planning process.

Beyond understanding landscape as only representational, performance and affect are important for understanding being-in-the-world (Bondi, 2005; Lorimer, 2005; Thrift, 2004). Although the negotiation of planning policy is specifically about determining what kinds of performances and practices can (legally) take place - for example, making room for experience as a tourist sojourning in the countryside or blocking access for such uses-justifications for these experiential values are usually translated into language through representations that undermine the legitimacy of discussing the meaningfulness and diversity of landscape values in public planning discourse. The example of the "Greenbelt walks" provides a glimpse into the how close the Greenbelt Plan implementation has come to including behavior and meaning in addition to discourse - and yet how far this still remains from meaningful incorporation in policy formation. As part of the creation of the Greenbelt, "Greenbelt walks" became signed and advertised, encouraging urban tourists to hike in the countryside. This has made room for particular kinds of exploratory experiences to take place to the chagrin of some farmers, who see their values consigned to traditionalist or econometric discourses represented by commodity groups or housing developers - or represented in terms of the critiques of sustainable farming or food-access discourses that are symbolically associated with more urban than rural interests. As the Greenbelt implementation process has not yet developed a platform for supporting 
negotiations about meaning and experiential values to different social groups, this example shows a disconnect between the kinds of experiential values invoked in efforts to stir up political will to support the Greenbelt and the transparent incorporation of those values in the policy process, where there is currently no space for consideration of experiences explored in the Greenbelt.

Understanding the idea of a "protected countryside" in this light — as an explicit policy tool for actively managing landscapes to reflect and intensify particular values, rather than merely a descriptive category for the rural landscape-enables us to consider how countryside as a symbolic landscape ideal has been used in the case of greenbelt policy making to construct consensus. The idea of countryside in Canada draws upon both British and American discourses, which have historically both been framed in terms of agrarian ideology. Countryside is "an amorphous term that has come to represent a whole bundle of ideas about life that draw their meaning in opposition to the city. To define countryside as a cultural landscape, the scholarly literature draws upon concepts including 'rurality' and the 'rural idyll', 'pastoral' and 'nature'” (Taylor, 2007: 72; cf. Bunce, 1994; Williams, 1973; Marx, 1964).

The tradition of cultural landscape studies critically explores the interaction of people and place with specific attention to the discourses and practices used to represent and manage the landscapes that are created through this interaction (Duncan and Duncan, 1988; Groth, 1997). In this tradition of representation, the landscape is understood to be not only constituted by static artifacts and symbols, but also by dynamic processes, all of which constantly shape and are shaped by social, political, economic, and environmental processes (Cosgrove, 1985; Antrop, 2005; Nassauer, 1995; Seymour, 2000). More recent work in cultural geography expands the understanding of landscape experience beyond representational geographies to consider the 
"manifold of actions and interactions" of the human and non-human (Anderson and Harrison, 2010: 2). However, for the study of environmental management, we see that the representational aspects of planning discourse continue to have most traction in understanding the nature of negotiation over landscape futures.

We combine the attention paid by cultural landscape studies to landscape formation and dynamics with political ecology's focus on the dialectic between power relations and environmental experience (Taylor and Cadieux, 2012). Our perspective recognizes the value of understanding landscapes as affective and performative as in the new cultural geography (Neumann, 2011; Anderson and Harrison, 2010) but for the purposes of understanding the Greenbelt, draws on political ecological approaches to understanding landscape meaning and on relational understandings of "the intertwined and co-constituent production of rural space through material and discursive phenomenon, processes and practices" (Heley and Jones 2012, 209). As such a relationally produced space, the form of the material landscape itself and also its representations in images, literature, and the media exhibit and influence the goals, aspirations, and practices of the people who shape and experience it (Marx, 1964; Williams, 1973; Cosgrove, 1985; Olwig, 2002). Consequently, in approaching questions of landscape politics, particular attention must be paid to the dynamic processes that constitute landscape, to the ways in which the meaning of landscapes such as countryside are negotiated (Cloke, 2003; Duncan and Duncan, 2004; Perkins and Thorns, 2001; Mitchell, 1996; Robbins, 2011; Zukin, 1991), and to the less visible (or voiced) aspirations, discourses, and power relations embedded in landscape. These are otherwise often smoothed over, or hidden, as not all people have equal access to or agency in shaping_or reading_particular landscapes (Duncan and Ley, 1993; Willems-Braun, 1997). 
The landscape studies approach underlies our argument that the Greenbelt Plan process may not incorporate tools to reconcile the tension between the abstract and material. The landscape approach highlights defensive tendencies in politics to stabilize particular power relations and environmental goals through particular representations of the material landscape (Duncan and Ley, 1993) — in this case the countryside and sprawl—and to delegitimize alternate readings of the landscape (Few, 2001; Willems-Braun, 1997). The effect is to open up space for particular kinds of practice and close off others. For example, Hurley and Walker (2004; also Walker and Fortmann, 2003) recount the struggle in the American West by environmentalists to read the landscape in terms of its ecosystem services, a reading rejected by ranchers. Similarly, environmentalists and farmers in the Greenbelt disagree over the future of farming and farm practices best suited to a Protected Countryside, particularly the use of pesticide- and fertilizerdependent cash grain crops (Pond, 2009: 424). The landscape approach is useful in thinking about how the environment (often represented in environmental management discourses as given and inherently worthy of preservation) is mediated by social understandings and ideology (Barnes and Duncan, 1992; Bunce, 1998; Eagleton, 1991). Competing ideologies regarding what is legitimate to do with urban and rural landscapes are often at the center of such management discourses when attempts are made to stabilize the meaning of particular landscapes in policy and to limit subsequent practices (see Abrams and Gosnell 2012 for a parallel discussion of how landscape ideology limits traditional ranching practice in rural Oregon). Such management discourses as the Greenbelt Plan for "protecting" countryside thus act as powerful forces in transforming already existing landscapes into very specific versions of those landscapes, privileging particular visions, values, and practices. 
The resulting landscapes reflect privileged interpretations readily identifiable to certain constituents and not to others, leaving certain visions of the landscape intact, but "writing over" others (Denevan, 1992; Jacobs, 1996; Martinez, 2003; Pratt, 1999). For example, although countryside means many things in the Greenbelt (e.g. agricultural-, natural-, or heritage-related), in practice, plans to protect countryside tend to focus on idealized pastoral landscape aesthetics (Bunce, 1994), privileging visual preference for or symbolic associations with countryside landscapes - and benefitting exurban residential landowners and urban tourists at the expense of rural livelihoods. Imagined landscapes discursively overwrite existing landscapes, and, at times, the imagined or symbolic landscape has as much or more weight than the actual place (Fairhead and Leach, 1996). This slippage between the abstract and material has significant political consequences, with the overwriting elites having not "merely filled the gaps nor followed the clues in the landscape," thereby working toward the common good promoted as the justification for the Greenbelt; "they have created something quite apart and quite their own" (Duncan and Duncan, 1988: 123). At its worst, the Greenbelt risks writing over the complexity of the lived landscape by shutting down conversation about alternative countryside futures in the absence of a proactive dialogue about what sustainable investment in the countryside looks like (Mcfarlane, 2009).

The insistence of the landscape approach on understanding how material substance and abstract ideals are inextricably and dynamically linked complicates the collaborative environmental management framework in which Greenbelt Plan is implicitly set. The implementation of the Greenbelt Plan as countryside legislation has been widely critiqued as the imposition of elite landscape representations. In this contentious context, understanding "countryside" as a specific set of discursive frameworks for reconciling urban and rural 
landscape processes helps keep in sight the need for and usefulness of ongoing negotiations over the contested question of what it means to protect countryside.

\section{Constructing (and contesting) consensus with iconic countryside}

In the discussions that led up to the current Greenbelt Plan, the idea of "countryside" was invoked with the hopes that it would serve a facilitating role. As an umbrella framework suggested by the Task Force to include a wide and diverse range of possible values for the Greenbelt landscape, this idea of "countryside" was adopted because it was considered to have a sufficiently understandable and stable meaning to serve as the central conceptual framework for negotiating the Greater Golden Horseshoe Greenbelt. In the context of the broader history of planning and managing the relationship between urban and rural lands in the Toronto region, this label "countryside" has generally been used to signify a wide range of landscapes whose main commonality is a need to be protected from urbanization (both in terms of conversion to housing landscapes and also to the quarries used for building materials: OGTA, 1992; GTSB, 2001; GTACC, 1999). In this case, "countryside" was used by the province as a policy designation intended to capture unruly strands of discourse around controlling sprawl, and as an overarching concept framing the changes to the material landscape that would be worked out in detail at the local level, as landscape processes were modified to meet the vision of the Plan. As the task force charged with developing recommendations for the constitution of the Greenbelt realized, the countryside has consistently represented diverse hopes for the near-urban rural landscape (MacIsaac, 2004). Consequently, the Greenbelt was intentionally constituted around the idea of countryside in order to provide an inclusive framework for negotiation that would maximize common ground and political acceptance of the Greenbelt at the provincial level. 
The Plan acknowledges the need to balance completing values (for agricultural systems, natural systems, etc.). The version of countryside the Province identified with the Greenbelt via Protected Countryside, however, does not make any mention of the framework of Protected Countryside as a domain of values to help orient negotiations between different land use goals. In defining the Protected Countryside and casting it in the dual and simultaneous role of a limit to the city's growth and a permanent protector of the natural heritage and agricultural land base, the province applied an iconic landscape ideal, rather than acknowledge a vibrant mix of complex and negotiated landscape processes. The Greenbelt Plan's representation of the countryside reifies a generic, distant, nostalgic, pastoral landscape (Bunce, 1994). This archetype serves as a convenient shorthand for the actual complexity of the countryside, projecting an image of a predominantly agrarian landscape, served by traditional or "heritage" rural communities within a backdrop of natural environment (OMAH, 2005: 12-14). In this vision, natural features and resources are protected and a few open spaces are available for public enjoyment as long as they do not disrupt the dominant agricultural economy. Although it may accurately evoke the feelings many urbanites have for the countryside, the symbolic and idealized nature of this version of countryside may make it difficult to relate to the existing messiness of the fringe landscape, or to the planning decisions that need to be made to address the management of pressures for urbanization. Negotiation between the ideal abstract countryside and existing material landscape is taking place through the implementation of the Plan, but the imposition of some people's abstract countryside ideals involves suppression of lived experience.

As an abstract landscape, the Protected Countryside achieved for the provincial government its goal (promised in their election platform) of "vowing to stop development that 
encroaches on valuable farmland, waterways and recreational areas" (Mallan, 2003); in polls assessing the approval rating for the Greenbelt in 2007 and 2009, it achieved $89 \%$ and $93 \%$ approval in the province, and was considered to have dramatically improved approval for the Liberal party’s leadership (Environmental Defence, 2007; Environics, 2009). However, reception of the Greenbelt in the years since its announcement still suggests tensions between consensus and contests: despite these high approval ratings, farmers and other land owners have reacted to the rebranding of the city's countryside with challenges by protesting in a number of venues (Pond, 2009; Walton, 2012; Tomalty and Komorowsky, 2011: 29).

Protected Countryside in the Greenbelt was explicitly adopted as a conceptual framework designed to mitigate conflicts between competing landscape ideals and practices by eliciting consensus about the relative value of near-urban rural landscapes in opposition to sprawl. Conflicts that arose during the planning process and that continue to mark the implementation of the Plan include struggles over a number of questions, including: whose land is developable (particularly in relation to expectations about future urbanization and to patterns of speculative investment); what urbanization processes and urban-related resource functions in existing settlement areas (including roads and aggregate extraction and market agriculture) will look like and how they will function; priorities for making or keeping things "rural"; and landscape management practices, particularly agricultural practices with effects on water (Bunce and Maurer, 2005; Cadieux, 2011; MacIsaac, 2004; Punter, 1974; Woods, 2011). Despite the introduction of the idea of countryside as metadiscursive — calling for explicit consideration of the range of different symbolic values that would be identified in the Greenbelt landscape, and that would also need to be translated into plans for maintaining the material instantiations of these values - the assertion, rather than development of a process for exploration, of these 
symbolic values and the ways they are produced in Greenbelt landscapes seems to forego a significant opportunity for discovering and developing diverse ways that the Plan's implementation might address the problems it was designed to fix.

Instead of an effective framework for exploratory collaboration, the idea of Protected Countryside was put forward as an already coherent symbolic proposition difficult to resist, situated at the intersection of a vision for a sustainable rural environment and a plan for good management of the Toronto region's urban growth. The iconic landscape of the countryside was used in this case by policy-makers as a neat and closed discursive strategy, an icon or emblem (Hajer, 1995) for asserting already achieved common ground to promote and secure buy-in to the greenbelt idea. The widespread urban support for the Greenbelt suggests resolution of the central concern of the Liberal party that created the Greenbelt: that lack of public support might result in the overturning of the Greenbelt legislation in the future. However, the very process of making the Greenbelt landscape more legible to Toronto-region constituents as symbolic countrysideand hence more supportable as Protected Countryside - also supports particular ways of understanding and shaping landscapes, ways that seem to us to be in tension with the participatory vision for shaping land use futures that the Greenbelt Plan at least implicitly embraces. Section 5, for example, states that "government and agencies...work collectively to manage and guide land use within the Greenbelt." Close examination of tensions within the idea of countryside calls into question the high levels of consensus supporting the Greenbelt. Most specifically, there are tensions between the ways the Greenbelt Plan has set out to address concerns over sprawl and the justifications provided for protecting the landscape now captured by the Greenbelt. 
The detailed landscape planning required to keep the Greenbelt's promise as a visible, experiential countryside protected from sprawl falls to local municipalities and the local planning process. At the local level, management of landscape change determines whether the landscape of the Protected Countryside will indeed be read as countryside: does the experience of the landscape meet the ideal? Although there may be relatively high consensus that protecting countryside is a good idea, at the implementation stage in each location where protecting countryside is proposed, we witness many of the struggles described above that tend to undermine urban growth management (Hurley and Walker, 2004). The simplification evident in applying an idealized category such as Protected Countryside to such a varied landscape points out the ways in which Protected Countryside is an abstracted category that performs important discursive work; we argue that this discursive work could also be used to frame more exploratory engagement with the Greenbelt process.

While very few people have argued that the countryside itself was not worth protecting, many people did argue against the inclusion of their particular parcels in the Protected Countryside. For example, a well-organized and well-represented landowners' group from the northeast sector of the Greenbelt, in their submission to the Greenbelt Task Force during the public consultation period following release of the draft plan, argued that their land was not worthy of inclusion in the Greenbelt as it did not have the kind of special distinguishing qualities making it suitable for protection. They did not dispute the idea of the Greenbelt in their submission, even tangentially; they argued against the inclusion of their particular land area in the Greenbelt because it was not special enough for inclusion as protected countryside - and instead suitable for urban development. In this example, the strength of the countryside ideal at the abstract level is recognized and the overall policy framework is not politically threatened, but 
in the attempt to exempt particular parcels, we can see the whittling-away process that threatens the integrity of plans such as the Greenbelt Plan over time.

Although the abstract category of countryside attempts to frame the Greenbelt landscape in a coherent way, there are dissonances between the urban-centred popular imagination of the countryside and the lived-in experience of the landscape of the Toronto region's rural areas; the material landscape of industrialized farming, aggregate mining, and untidy rural uses does not fit easily with the pastoral amenity vision of the landscape — and rural preservation efforts face challenges well documented by rural geographers and political ecologists in terms of the ways that attempts to protect working rural landscapes end up creating simulacra, simplified and prettified ruralesque landscapes that deliver nice views to those who can afford them rather than the public benefits promised (Baskind-Wing, 2009; Murdoch and Lowe, 2003; Walker and Hurley, 2011). The platonic ideal of countryside must be constructed on top of the messy reality of a wide range of fringe landscapes in the Toronto region, from scenic rolling countryside to flat plains of row-crop agriculture, from exurban estates to trailer parks, from junkyards to forested Provincial parks, and from gravel pits to wetlands.

The creation of the Greenbelt Plan involved the overwriting of the Toronto fringe landscape by the ideal of the protected countryside, quite likely privileging an elite, urbancentred view of the role of the countryside in stopping sprawl. Despite repeated explanations by provincial authorities that development rights were not being revoked or expropriated because the land in question (with very few exceptions) had never been zoned for urban expansion, the abstract countryside protected in the Greenbelt has been seen as "expropriation without compensation" by many farmers (Lindgren 2004), to whom the stewardship of much of the 
protected countryside falls. For many of these farmers, a near-urban local foodlands vision was consequently seen as an imposition of unsympathetic and unrealistic urbanites.

When the abstract idea of stopping sprawl is confronted with its impact on the material landscape and on the livelihoods and lifestyles of the people that live there, the abstract translates into the local and the personal: why your land, in this place, is required to meet this societal objective. Much of the success of the Greenbelt is in the hands of the farmers whose day-to-day decisions, ongoing capital and labor investment, and patterns of everyday life will shape the landscape of the Protected Countryside. As one pamphlet from the Friends of the Greenbelt Foundation declares, "Greenbelt farmers care about the quality of life for everyone!" (n.d. 59). Thus the farmers, along with their landscapes, are being discursively re-created to fit with the ideal of the protected countryside.

\section{Who speaks for countryside?}

The Greenbelt benefits a largely urban public whose quality of life is based on the clean drinking water (and, to some extent, local food) to be provided by the Greenbelt, as well as the amenity benefits of a landscape protected from sprawl. Public support operates at the level of generalities, with some supporters admitting they have never even visited the area. For example, a huge quilt celebrating the Greenbelt, which has become a highly-visible travelling exhibit at Greenbelt events, was created by a group of women, several of whom admitted they had never been to see the Greenbelt (Ontario Crafts Council, 2010). For others, experience of the Greenbelt as producers or consumers is shaped by specific everyday engagements with the landscapematerial and symbolic. However, taking into account a wide precedent for ignoring relational specificities in favor of symbolic generality in the environmental management literature 
(Cadieux, 2011; Innes, 1992; Innes and Gruber, 2005; Ley, 1995; Punter, 1974; Walker and Fortmann, 2003; Woods, 2011), the process that has constructed the Greenbelt Plan so far leaves us concerned about how much effort will be put into achieving the Protected Countryside's public benefits.

The political success of the Greenbelt so far has rested on political alliances, particularly those resting on the desirability of near-urban rural landscapes in the abstract. The most significant challenge to the planning vision embodied in the Plan comes from an equally abstract landscape ideal having to do with property rights and government intervention in those rights. Attending to the power relations inherent in who speaks for the countryside and for the benefits associated with it could help ground discussion of abstract landscapes in the material landscapes where management processes occur, and where the often-hidden agendas in the slippage between abstractions and a specific, experienced material landscape can be called into discussion more easily.

The current location and extent of the Greenbelt includes categories of landscape features that do not remain constant across its extent. The relative importance of these landscape features shifts when surveying the Greenbelt through different lenses: the supply and location of exceptionally productive farmland, forests, watercourses, and other natural resources, including recreational amenities such as golf courses and ski hills; the location and network of water, roads, power, and telecommunications; and the political geography of urban governments (Ding et al., 1999). These perspectives translate into multiple expectations, many of which are articulated through dominant discourses, such as those having to do with agriculture and ecology, as described above, or with property and development rights and economic impacts (Walker and Fortmann, 2003; Woods, 2011). 
Further, the designation of countryside is often presented as if it straightforwardly describes a landscape, or a given landscape ideal — and as if its status as countryside just as straightforwardly justifies normative action, such as protection. This complicates the process of determining what kinds of land uses and landscape processes fit with different constituents' aspirations for countryside. It also makes it more difficult to see how much the idealized landscapes associated with countryside represent specific ideologies and preferred landscape processes and outcomes. In other words, in the face of specific demands being made on people's properties, it becomes salient that countryside landscape ideals come with preferred speakers already associated with countryside: privileged, white, potentially even British (Ley, 1995; Bunce, 1994). Critical consideration of these associations with countryside raises questions that need to be addressed in determining how public benefit will be delivered and negotiated in Greenbelt governance. Who has agency in the countryside? For whose benefit is something like a greenbelt instituted? In what ways are ideals of countryside written into the landscape - and how can these normative ideals be broadened or made more complex to reflect diverse and competing goals?

The very concept of protecting a "countryside" raises a number of additional critical questions. The landscape is a site of competition between exurbanization (Taylor, 2011), sensational natural environments such as the Niagara Escarpment, and a variety of forms of agriculture from corn and soybeans to ginseng and ginger - and a considerable amount of the agitation for countryside protection reflects varying reactions to a sense that decisions about this competition are often negotiated in spaces of abstract governance rather than in the communities involved (Woods, 2011; Hurley and Walker, 2004). One of the most contentious issues in the implementation of the Greenbelt Plan involves the question: who is empowered to speak for the 
Protected Countryside? A Greenbelt Council and the Friends of the Greenbelt Foundation have been established to facilitate and represent the interface between the implementation of the Greenbelt and the public; the Council's primary role is to provide advice to the government on Greenbelt protection matters, while the Foundation is responsible for promoting the Greenbelt and funding projects and research that conform to the representation of the Greenbelt as productive and accessible countryside.

Within the civil service, the Planning and Policy Branch of the Ministry of Municipal Affairs and Housing addresses Greenbelt issues and provides advice to the Advisory Council and the Minister. Considerable danger exists that the voices that speak for the Greenbelt will continue to be the governmental representatives whose legitimacy with the general public is not certain. An additional concern is that environmental management decisions over these lands will be disproportionately influenced by industry groups, for example, housing developers and commodity crop associations. Although considerable language in the Plan (Section 5) refers to the possible "meaningful" role for the Greenbelt Council in "helping to coordinate efforts of municipalities, conservation authorities, associations and other stakeholders" and on building the "ability of local communities and associations to provide meaningful input and information," the specific mandate for carrying out this work of facilitating collaborative planning has not been granted, except for the explicit expectation that "the Greenbelt Council will play an important role in helping to shape and/or focus the nature and/or content of the [10-year] review." In other words, the details of the "how" of implementation is pushed off into the realm of local municipal negotiations - and venues for potentially supportive critical consideration of the Plan's progress, such as the 2011 Global Greenbelts Conference, have, instead (to considerable consternation), been organized as non-substantive celebrations. 
The establishment of expectations for the meaningful incorporation of local knowledge and community capacity to support Greenbelt goals, despite the pre-existing social and power relations associated with countryside, expresses optimism about the possibility of farmers and others being able to populate the countryside with their goals and ideals through the ongoing process of constituting the Greenbelt. In their role overseeing the implementation of the Plan and the review process, the advisory Greenbelt Council (and, to some degree, the Friends of the Greenbelt Foundation as advocates) are faced with the tasks of matching competing visions and interests with the principles of the Plan and of guiding this process along with municipalities as they implement the Greenbelt Plan through the planning process. As Gorton, White, and Chaston (1998: 229) observe in their analysis of the tension between communitarian and individualist values embedded in the rural idyll, "[the rural idyll] does not in itself provide a telos for settling disputes between competing plans in rural localities. Crucially then, for all the long tradition of 'rural worship', there has never been a single, clear and consistent notion of what the countryside should be." This analysis underlines the usefulness expressed in the collaborative environmental management literature of critically exploring the range of expert and community visions of countryside, and of making more explicit and transparent the motives and plans associated with competing rural idylls, in addition to addressing the often elite power structures embedded in countryside representations and in the environmental science used to support particular management goals for countryside (Innes, 1992; Innes and Booher, 1999; Innes and Gruber, 2005; Mandarano, 2008; Saarikoski, 2000; Selin and Chavez, 1995; Wondolleck and Yaffee, 2000). 


\section{Conclusion: Reconciling multiple expectations of landscape processes with the simplified countryside}

While it is generally considered legitimate to denounce sprawl and to promote conservation of agricultural and ecological function, the landscape values of countryside are less easily expressed or endorsed. A difficult transition is involved in the shift from an impermanent city's countryside - the peri-urban region at risk from exurban incursions and speculative valuation for future urban development — to a permanent countryside, especially within a global economic system where agriculture faces significant challenges beyond urbanization. While reasonable consensus on the benefits of greenspace (including "countryside") in the Toronto region may have been achieved, in this larger global context, it appears that protecting landscapes through designation alone is unlikely to be sufficient to save the working countryside. Given that the government protection offered by the Greenbelt is not tied to government economic support through changes to tax policy, expropriation, purchase of land, or of development rights (particularly relevant in the case of agriculture), how will landscapes within the Protected Countryside of various qualities and identities differentiate and maintain themselves? The economic impact of designating lands as Greenbelt is defined in different ways for different users: for the regional agricultural economy, for aggregate extraction, and for residential and commercial development. The key question for all of these groups is what will it mean for their land use and land transactions and livelihood decisions to be in the Greenbelt and the Protected Countryside?

These issues and constituencies define the diverse realities of the Protected Countryside that are being confronted as the Greenbelt Plan matures. The reconciliation of this reality with the abstract version of the countryside requires detailed knowledge of how the countryside 
functions, as well as recognition of the symbolic features such as landmarks and vistas that make this landscape meaningful to different constituencies. An understanding of the countryside as both materially experienced and also as abstractly conceived is a necessary platform for negotiating the meaning and purpose of countryside. This will involve (and we hope scholars will continue to be involved in) both public participatory processes and focused research endeavors that set out to explore how the values, aspirations, and practices of those who have direct stakes in Greenbelt lands have shaped the present and will influence the future landscapes of the Protected Countryside as well how its meaning and function are re-created, contested, and negotiated. ${ }^{7}$ For all the benefits that the Greenbelt confers to the Toronto region, its future success is caught up in the tensions between the abstract and material landscapes and the question of who speaks for the countryside. From the perspective of landscape studies and political ecology, engaging with landscape meaning in the political process points to a way forward for the Greenbelt and for other similar major planning initiatives. Landscape meaning is wielded in politics and shapes the decisions that are made in city regions. How the meaning of countryside is stabilized, or not, as the Greenbelt matures will reflect—and be influenced bycontemporary competing valuation of city and country.

Rather than continue to perpetuate conventional planning process at the local level, now that most municipalities have updated their local comprehensive plans to reflect and incorporate the policies of the Greenbelt Plan, the approaches of collaborative environmental management could be incorporated into future decision making about land use and activities within the Protected Countryside. We would hope that the negotiative process of the Greenbelt's long term

\footnotetext{
${ }^{7}$ We are considerably influenced in this normative position by the work of publicly-engaged scholarship or "intervention research" that remains with problems related to the production of social spaces and solutions proposed for these, evaluating their incremental progress and trying to help figuring out how to address the subsequent challenges raised by applying prior constructs and solutions (Lefebvre, 1991; Hatchuel, 2000).
} 
implementation could be robust and flexible enough to resist the undermining of the rich and multiple meanings of countryside. Within the promise of the countryside ideal, existing landscape actors are targeted as willing and able to fulfill particular roles represented by the broad public benefits that the Greenbelt is intended to achieve. Linking those roles (without which the Greenbelt will not necessarily succeed) with the landscape management negotiations within the planning process would help. The combination of landscape studies and political ecology with collaborative environmental management sets out an approach that is intended to provide the setting for a dialogue that includes those stakeholders on whose individual landscape decisions the success of the Plan rests. Within this approach to the planning process, knowledge is not limited to experts and the process is not dictated by measurability and predictive certainty, but instead includes local, landscape-level insight and knowledge from those with lived experience and engagement with place in discussion with scientific and expert analysis. In the process, a diverse array of participants - including resource producers and people whose access to Greenbelt spaces has been marginalized, as well as constituents with specific knowledge of rich layers of the Greenbelt landscape (e.g. indigenous people, birders, foragers, hunters, longtime residents, forest managers), as well as those more commonly associated with the Greenbelt, such as farmers, urban recreationalists, and developers_- build relationships and learn from each other.

We recommend that local municipalities provide the forum for collaborative planning but recognize that this requires a shift in perspective from a goal-oriented planning process (“does this site-specific proposal meet the policy in the comprehensive plan?") to also include more open-ended search for what the countryside means for each set of localized landscape settings (“how can this proposal best support the creation of our place's countryside landscape?"). Some 
provincial government assistance in training and facilitation would be required (Innes and Booher, 2010); this could be possible through a diversification of the Friends of the Greenbelt Foundation's strategy, which currently builds support via marketing. In the absence of such a collaborative approach to decision making, which deliberately extends the discursive creation of the countryside through dialogue with all of those who have a stake in the Greenbelt, the oversimplified overwriting of the abstract landscape onto the material may instead stifle creativity and investment in the Protected Countryside and ultimately contribute to the Plan's demise.

As a case where an integration of scholarly and practitioner approaches to negotiating different land-use goals was very nearly realized via the construct of the Protected Countryside, the study of the GGH Greenbelt provides broader lessons for the practice of planning and governance. Especially as an example of a return to regional-scale planning under a government that has been steadily devolving land-use governance following neoliberal principles (Gilbert et al., 2005), this case illustrates the continuing challenges of contemporary governance of urbanrural relationships, especially in the context of a dialectical tension between pushing implementation to local levels while rules are centrally rationalized and negotiated out of the reach of public participation. Focusing on the distance between assertions of the value of public participation and the incorporation of public negotiation of value in the Greenbelt implementation, our analysis has centered on the persistent need to negotiate three themes that have implications beyond this case study: anti-urban ideology in rural planning, competition between urban and rural social economies, and opposing environmental management goals. 
Given these themes, the analysis presented in this paper demonstrates that landscape studies and political ecology are extremely useful for analyzing planning policy and implementation. We expand briefly on some implications of each of these three themes below to underline the broader usefulness of the approach we have outlined for unpacking the claims of working toward a common good that are used to justify interventions such as the Greenbelt. While such claims are potentially plausible, to the degree that the processes used to implement land-use policies are captured by status quo power relations, landscape protection measures often benefit the few at the cost of the many, even in contexts of active work toward environmental justice, partly because so many of the ways power is embedded in landscape processes are implicit and are not given voice in policy implementation negotiations.

Calling for ways to bring contested goals and tools for achieving them into discussion more easily, we have focused on examples of key themes that illustrate the tensions between abstract and material landscapes where we most often see misunderstandings — often because people talking about abstract landscapes have mistaken them for material ones, do not see the conflicts and tensions involved, or do not have good tools for managing them, especially given the challenges of acknowledging how much the ideals associated with preferred landscapes like countryside represent specific ideologies and constituencies. (The same could be said for other preferred landscapes such as gentrifying urban neighborhoods.) As a strategy used to maximize political acceptance at the expense of alignment with the experience of landscapes, we show how easily the political use of abstract ideals such as "countryside" to sidestep predicted conflicts leads to disconnects in the implementation process when material landscapes do not conform to the ideology imposed on them. Failures to engage the materiality of landscape experience along with high-level expert abstractions continually calls these abstractions into question and 
undermines capacity for local implementation as well as the political will that abstract landscape ideals are used to generate.

First, it is important to note that the Greenbelt was created through a process that was intended to allow broad public participation, but perhaps suffered from problems common to many large planning processes, especially around projects where those in power fear facilitating the exploration of competing landscape values because they are uncertain what can be delivered in response. Instead of adopting the landscape concept of countryside as a framework for proactively integrating competing values, the organizers of the Greenbelt planning process assumed that those who were interested could and would become involved. They skirted significant issues of class, race, and power that undergird discomfort about whose landscape gets to be protected as countryside, and in so doing, also missed opportunities to explicitly acknowledge and include important efforts in the Plan (or were late to engage them)—for example, attempts to facilitate more connection between Greenbelt land-use practices and immigrant communities in Ontario (see the work of the Vineland Research and Innovation Centre in Niagara).

Second, the Greenbelt implementation suggests that negotiative processes need to be organized not only for resolving conflicts between stakeholder interests and agendas, but also for getting beyond labelling of land-use designations to a constructive dialogue about how current realities can be accommodated within abstract environmental management ideals. As suggested by the collaborative environmental management approach, in cases like the Greenbelt, this needs to involve key constituents on an ongoing basis and at the local level in the negotiation of such issues as public access to private land, farmland severances, farm income diversification, and environmental stewardship. Perhaps more than anything, such processes need to focus on how to 
engage those who control the everyday management of landscapes in discussions that will enable them to adapt their agendas to environmental management visions (in the case of the Greenbelt, the largest land-owning group in much of the Protected Countryside are housing developers). Although scholars concerned with the neoliberalization of urbanization policy call attention to the pitfalls of public-private partnerships and growth agendas (Gilbert et al., 2005), Innes and Booher (2010) suggest that productive engagement between public and private interests is possible if developers see potential in land-use decision making negotiated in this way as preferable to more conventional lengthy and expensive litigious avenues. Such discussions might also provide opportunities to cultivate investment in plans such as the Greenbelt by building on the outpouring of enthusiasm expressed in consultation sessions that often influence the creation of plans, and also by including a broader constituency of urban and peri-urban residents in the negotiation of particular landscapes' futures. Such a broad constituency is arguably at the same time the perceived market and driving force for the developers who are seen to threaten countryside in most anti-sprawl efforts, and they are also the users of agricultural and recreational landscapes and the beneficiaries of the cleaner air, water, and ecosystems promised by the protection of agricultural and natural landscapes designated as "countryside."

Given the top-down approach of legislation such as the Greenbelt and the pitfalls of participatory planning (Hurley and Walker, 2004; Walker \& Fortmann, 2003), this is a tall order. Our third point is a recognition that the need to better reflect the countryside as it is experienced will provoke tension between the coherence of landscape plans (and their neat marketability that rests on this coherence) and their correspondence to protected landscapes as they are experienced by all those who value them. If designations such as Protected Countryside are to sustain the inevitable pressures of change, they need to be flexible, as well as robust, and managed with a 
strategy that is responsive to change and innovation without compromising the basic principles of plans such as that for the GGH Greenbelt.

Everything about the Greenbelt will require the cooperation of those who live in and depend upon the landscapes included by the Greenbelt. In its failure to provide a new and genuine paradigm for discussing the future of the Greenbelt, the Plan does not suggest possible ways to interlace greenspace with urban structure beyond a traditional Town and Country planning approach that separates urban and rural land uses. The Greenbelt may be conceptually easier to grasp as an urban containment boundary than as a complex and multivalent landscape; however, as Protected Countryside it has to be more than just a wide green line. A functioning countryside depends on the interaction of many uses and activities; as scholars attentive to the challenges facing sustainability governance have persuasively argued in calls to help link political process and environmental understanding through local public process (Demeritt, 1994;

O’Riordan, 2004), it is not possible to protect valued environments without inclusive and ongoing conversations about and governance mechanisms for the "whys" and "hows" of both the abstract and material landscapes, past, present, and future.

\section{REFERENCES}

Abrams, J. and Gosnell, H., 2012. The politics of marginality in Wallowa County, Oregon: Contesting the production of landscapes of consumption. Journal of Rural Studies 28, 30-37. 
Amati, M. and Taylor, L., 2010. From green belts to green infrastructure. Planning Practice and Research (Special Issue: Debating the future of green belts) 25(2), 143-155.

Anderson, B. and Harrison, P., 2010. Taking-Place: Non-representational Theories and Geography. Ashgate, London.

Antrop, M., 2005. Why landscapes of the past are important for the future. Landscape and Urban Planning 70 (1-2), 21-34.

Barnes, T. and Duncan, J., Editors, 1992. Writing Worlds: Discourse, Text \& Metaphor in the Representation of Landscape. Routledge, London.

Baskind-Wing, S., 2009. Reclaiming Rural Character: Conservation, Conflict, and Nostalgic Landscapes of Orcas Island, WA. Ph.D. dissertation, Rutgers University.

Bondi, L., 2005. Making connections and thinking through emotions: Between geography and psychotherapy. Transactions of the Institute of British Geographers 30, 433-448.

Bunce, M., 1994. The Countryside Ideal: Anglo-American Images of Landscape. Routledge, London.

Bunce, M., 1998. Thirty years of farmland preservation in North America: discourses and ideologies of a movement. Journal of Rural Studies 14(2), 233-247. 
Bunce, M. and Maurer, J., 2005. Prospects for Agriculture in the Toronto Region: The Farmer Perspective. Neptis Studies on the Toronto Metropolitan Region, Toronto.

Cadieux, K.V., 2008. Political ecology of exurban 'lifestyle' landscapes at Christchurch's contested urban fence. Urban Forestry and Urban Greening, 7(3):183-194.

Cadieux, K.V., 2011. Competing discourses of nature in exurbia. GeoJournal 76(4) (doi: 10.1007/s10708-009-9299-0).

Cadieux, K.V. and Taylor, L.E., 2012. Landscape and the Ideology of Nature in Exurbia: Green Sprawl. Routledge, New York.

Cloke, P., Editor, 2003. Countryside Visions. Prentice-Hall, London.

Conley, A. and Moote, M.A., 2003. Evaluating collaborative natural resource management. Society and Natural Resources 16(5), 371-386.

Cosgrove, D., 1985. Prospect, perspective and the evolution of the landscape idea. Transactions Institute of the British Geographers 10, 45-62.

Demeritt, D., 1994. Ecology, objectivity and critique in writings on nature and human society. Journal of Historical Geography 20(1), 22-37. 
Denevan, W.M., 1992. The pristine myth: The landscape of the Americas in 1492. Annals of the Association of American Geographers 82(3), 369-385.

Ding, C., Knaap, G. and Hopkins, L., 1999. Managing urban growth with urban growth boundaries. Journal of Urban Economics 46, 53-68.

Duncan, J., 1990. The City as Text: The Politics of Landscape Interpretation in the Kandyan Kingdom. Cambridge University Press, Cambridge.

Duncan, J. and Ley, D., Editors, 1993. Place/Culture/Representation. Routledge, New York.

Duncan, J. and Duncan, N., 1988. (Re)reading the Landscape. Environment and Planning D 6, $117-26$.

Duncan, J. and Duncan, N., 2004. Landscapes of Privilege: The Politics of the Aesthetic in an American Suburb. Routledge, New York.

Eagleton, T., 1991. Ideology: an Introduction. Verso, New York.

Environics Research Group, 2009. Measuring the Possibilities: Greenbelt Public Awareness 2009. (sponsored by Friends of the Greenbelt Foundation)

http://www.greenbelt.ca/webfm_send/542. 
Environmental Defence, Ontario Greenbelt Alliance, 2007. 2007 Greenbelt Report Card: $2^{\text {nd }}$ Anniversary Edition.

http://www.environmentaldefence.ca/reports/GreenbeltReportCard_FINAL.pdf.

Fairhead, J. and Leach, M., 1996. Misreading the African Landscape. Cambridge University Press, Cambridge.

Few, R., 2001. Containment and counter-containment: planner/community relations in conservation planning. The Geographical Journal 167(2), 111-124.

Friends of the Greenbelt Foundation, n.d. My Local Greenbelt Shopping guide, 59.

Friends of the Greenbelt Foundation, 2011. Global Greenbelts Conference: Overview and Proceedings. Toronto.

Gilbert, L., Wekerle, G.R. and Sandberg, L.A., 2005. Local Responses to Development Pressures: Conflictual Politics of Sprawl and Environmental Conservation. Cahiers de Geographie du Quebec 49(138), 377-92.

Gorton, M., White, J. and Chaston, I., 1998. Counterurbanisation, fragmentation and the paradox of the rural idyll. In: Boyle P. and Halfacree K. Editors, Migration Into Rural Areas. John Wiley \& Sons, New York. 
Greater Toronto Area Co-ordinating Committee (GTACC), 1999. Visions for the Countryside. Report of the Rural GTA Working Group, Toronto.

Greater Toronto Services Board (GTSB), 2001. Draft GTA Countryside Strategy. Toronto.

Groth, P., 1997. Frameworks for cultural landscape study. In: Groth P. and Bressi T., Editors, Understanding Ordinary Landscapes. Yale University Press, New Haven 1-21.

Hajer, M., 1995. The Politics of Environmental Discourse: Ecological Modernization and the Policy Process. Oxford University Press, Oxford.

Hatchuel, A., 2000. Intervention research and the production of knowledge. In: Cerf, M., Gibbon, M., Hubert, B., Ison, R., Jiggins, J., Paine, M., Proost, J., Röling, N., Editors, Cow up a Tree: Knowing and Learning for Change in Agriculture. Institut National de la Recherche Agronomique, Paris, 55-68.

Heley, J. and Jones, L., 2012. Relational rurals: Some thoughts on relating things and theory in rural studies. Journal of Rural Studies 28, 208-217.

Hemson Consulting Ltd., 2012. Greater Golden Horseshoe Forecasts to 2041: Technical Report. (last accessed February 2013) http://www.hemson.com GGH Forecast Committee, Toronto. 
Hurley, P. and Walker, P., 2004. Whose vision? Conspiracy theory and land-use planning in Nevada County, California. Environment and Planning A 36.

Innes, J.E., 1992. Group processes and the social construction of growth management: Florida, Vermont, and New Jersey. Journal of the American Planning Association 58(4), 440-453.

Innes, J.E. and Booher, D.E., 1999. Consensus building and complex adaptive systems: A framework for evaluating collaborative planning. Journal of the American Planning Association 65(4), 412-23.

Innes, J.E. and Booher, D.E., 2010. Planning with Complexity. Routledge, London.

Innes, J.E. and Gruber, J., 2005. Planning styles in conflict: The Metropolitan Transportation Commission. Journal of the American Planning Association 71(2), 177-88.

Jacobs, J.M., 1996. Edge of Empire: Postcolonialism and the City. Routledge, New York.

Lefebvre, H., 1991. The Production of Space. Translated by Donald Nicholson-Smith. Blackwell, Oxford.

Ley, D., 1995. Between Europe and Asia: the case of the missing sequoias. Ecumene 2(2), 185210. 
Lorimer, H., 2005. Cultural geography: The busyness of being 'more-than-representational.' Progress in Human Geography 29(1), 83-94.

Mallan, C., 2003. Liberals put Golden Horseshoe growth on hold for a year; Protection act affects land from Niagara Falls to Lake Scugog. Toronto Star, A01.

MacIsaac, R., 2004. Presentation on the Greenbelt Task Force in the panel 'Restoring our Home: Think Local.' Linking Landscapes Symposium: Planning for Restoration of our Urban and Rural Environments, Sep 29, Black Creek Pioneer Village. (Fieldnotes available from article authors.)

Mandarano, L.A., 2008. Evaluating collaborative environmental planning outputs and outcomes: Restoring and protecting habitat in New York - New Jersey Harbor Estuary Program. Journal of Planning Education and Research 27(4), 456-468.

Marx, L., 1964. The Machine in the Garden: Technology and the Pastoral Ideal in America. Oxford University Press, New York.

Martinez, D., 2003. Protected Areas, Indigenous Peoples, and The Western Idea of Nature. Ecological Restoration 21(4), 247-250.

McCormack, D., 2012. Geography and abstraction: Towards an affirmative critique. Progress in Human Geography 1-20. 
Mcfarlane, J., 2009. The Greenbelt Plan: The Change in Natural Systems Planning. Master's Major Research Paper, York University, Toronto.

McGuinty, D., 2004. Plan Will Curb Urban Sprawl. Speech by Premier of Ontario (October 28) http://www.premier.gov.on.ca/news/event.php?ItemID=4440\&Lang=EN.

Mitchell, D., 1996. The Lie of the Land: Migrant Workers and the California Landscape. University of Minnesota Press, Minneapolis.

Murdoch, J. and Lowe, P., 2003. The preservationist paradox: modernism, environmentalism and the politics of spatial division. Transactions of the Institute of British Geographers 28, 318-332.

Nassauer, J.I., 1995. Cultural Principles for Landscape Ecology. Landscape Ecology 10(4), 229237.

Neumann, R. P., 2011. Political ecology III: theorizing landscape. Progress in Human Geography 35(6), 843-850.

Niagara Escarpment Commission, 2005. The Niagara Escarpment Plan. Queen's Printer, Toronto.

Office of the Greater Toronto Area (OGTA), 1992. A Vision for the Countryside. Report of the Provincial-Municipal Countryside Working Group, Toronto. 
Olwig, K., 2002. The "Country" of the United States Contra the "Landscape" of America's New World in Landscape, Nature, and the Body Politic: From Britain's Renaissance to America's New World. In: Olwig, K, Editor (Madison: University of Wisconsin Press) 176-212.

Ontario Crafts Council, 2010. Quilt of Possibilities: Celebrating Ontario's Greenbelt. MPH Graphics, Toronto.

Ontario Ministry of Municipal Affairs and Housing (MAH), 2002. Oak Ridges Moraine Conservation Plan. Queen's Printer, Toronto.

Ontario Ministry of Municipal Affairs and Housing (MAH), 2003. Statement to the Legislature on the First Reading of the Greenbelt Protection Act (Dec 16). Queen's Printer, Toronto.

Ontario Ministry of Municipal Affairs and Housing (MAH), 2005. The Greenbelt Plan. Queen's Printer, Toronto.

Ontario Ministry of Treasury, Economics and Intergovernmental Affairs (MTEIA), 1978. The Parkway Belt West Plan. Queen's Printer, Toronto.

Ontario Ministry of Public Infrastructure Renewal (PIR), 2006. Places to Grow: Better Choices, Brighter Future, Growth Plan for the Greater Golden Horseshoe. Queen's Printer, Toronto. 
Ontario, Province of, 2004. Rouge Park Management Plan. Queen's Printer,Toronto.

Opdam, P., Steingröver, P. and van Rooij, S., 2006. Ecological networks: A spatial concept for multi-actor planning of sustainable landscapes. Landscape and Urban Planning 75 (3-4), 322332.

O’Riordan, T., 2004. Making a Difference in a Globalizing World. Transactions of the Institute of British Geographers 29(2), 234-247.

Perkins, H. and Thorns, D., 2001. Gazing or Performing? Reflections on Urry’s tourist gaze in the context of contemporary experience in the Antipodes. International Sociology 16, 185-204.

Pond, D., 2009. Ontario’s Greenbelt: Growth management, farmland protection and regime change in southern Ontario. Canadian Public Policy 35(4), 413-432.

Pratt, M.L., 1999. Alexander von Humboldt and the reinvention of America. In: Hall, S., Editor, Visual Culture: The Reader Sage, London, 421-434.

Punter, J., 1974. Urbanites in the Countryside: Case Studies of the Impact of Exurban Development on the Landscape in the Toronto-centred Region 1954-1971. Ph.D. dissertation, University of Toronto.

Robbins, P., 2011. Political Ecology: A Critical Introduction. 2nd ed. Blackwell, Malden, MA. 
Ryan, R., Gyula Fábos, J. and Allan, J.J., 2006. Understanding opportunities and challenges for collaborative greenway planning in New England. Landscape and Urban Planning 76(1-4), $172-191$.

Saarikoski, H., 2000. Environmental impact assessment (EIA) as a collaborative learning process. Environmental Impact Assessment Review 20(6), 681-700.

Selin, S. and Chavez, D., 1995. Developing a collaborative model for environmental planning and management. Environmental Management 19(2), 189-195.

Seymour, S., 2000. Historical geographies of landscape. In: Graham, B. and Nash, C. Editors, Modern Historical Geographies Pearson Educated Limited, Harlow, England, 193-217.

Smith, J.W., Davenport, M.A., Anderson, D.H., Leahy, J.E., 2011. Place meanings and desired management outcomes. Landscape and Urban Planning 101, 359-370 (doi:10.1016/j.landurbplan.2011.03.002).

Stein, T. and Anderson, D.H., 2002. Combining benefits-based management with ecosystem management for landscape planning: Leech Lake watershed, Minnesota. Landscape and Urban Planning 60(3), 151-161. 
Taylor, L., 2007. The Production of Nature in Planning for Urban Expansion: A Cultural Landscape Study of New Urban Growth in Oakville, Ontario. Ph.D. dissertation, University of Toronto.

Taylor, L., 2010. The Idea of Landscape in Planning at the City's Edge. In: Beesley, K., Editor, The Rural-Urban Fringe in Canada: Conflict and Controversy Brandon University Press, Brandon, MN, 348-62.

Taylor, L., 2011. No boundaries: Exurbia and the study of contemporary urban dispersion. GeoJournal 76(4) (doi: 10.1007/s10708-009-9300-y).

Taylor, L.E. and Cadieux, K.V., 2012. Sprawl and the Ideology of Nature. In: Cadieux, K.V. and Taylor, L.E., Editors, Landscape and the Ideology of Nature in Exurbia: Green Sprawl. Routledge, New York, 1-30.

Thrift, N. 2004., Intensities of feeling: Towards a spatial politics of affect. Geografiska Annaler 86B, 57-78.

Tomalty, R. and Komorowsky, B., 2011. Inside and Out: Sustaining Ontario's Greenbelt. Occasional paper 12. Friends of the Greenbelt Foundation, Toronto. 
von der Dunk, A., Grêt-Regamey, A., Dalang, T., and Hersperger, A., 2011. Defining a typology of peri-urban land-use conflicts-A case study from Switzerland, Landscape and Urban Planning 101(2), 149-156.

Walker, P. and Fortmann, L., 2003. Whose landscape? A political ecology of the 'exurban' Sierra Cultural Geographies 4(10), 469-491.

Walker, P. and Hurley, P.T., 2011. Planning Paradise: Politics and Visions of Land Use in Oregon. University of Arizona Press, Tucson.

Walton, M., 2012. Food and Farming: An Action Plan 2021. Greater Toronto Area Agricultural Action Committee, Toronto.

Walton, M., 2003. Greater Toronto Area Agricultural Profile: An Update of the GTA Agricultural Impact Study (1999). Planscape, Bracebridge, ON.

While, A., Jonas, A. and Gibbs, D., 2010. From sustainable development to carbon control: Ecostate restructuring and the politics of urban and regional development. Transactions of the Institute of British Geographers, New Series 35, 76-93.

Willems-Braun, B., 1997. Buried Epistemologies: The Politics of Nature in (Post)colonial British Columbia. Annals of the Association of American Geographers 87(1), 3-31. 
Williams, R., 1973. The Country and the City. Oxford University Press, New York.

Wondolleck, J.M. and Yaffee, S.L., 2000. Making Collaboration Work: Lessons from Innovation in Natural Resource Management. Island Press, Washington, D.C.

Woods, M., 2010. Rural. Routledge, New York.

Woods, M., 2011. The local politics of the global countryside: Boosterism, aspirational ruralism and the contested reconstitution of Queenstown, New Zealand. GeoJournal 76(4) (doi: 10.1007/s10708-009-9268-7).

Wylie, J., 2010. Cultural geographies of the future, or looking rosy and feeling blue. Cultural Geographies 17(2), 211-217 (doi: 10.1177/1474474010363852).

Zukin, S., 1991. Landscapes of Power: From Detroit to Disney World. University of California, Berkeley. 